
NUCLEAR

SAFETY

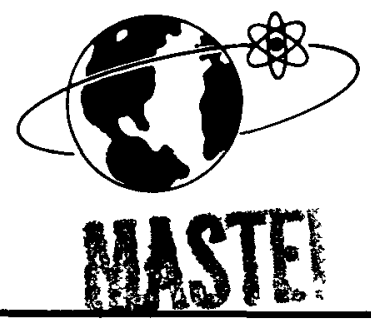

SC-RR - 70-881

\title{
A THEORETICAL EXPLANATION \\ OF A VERTICAL FLIGHT FREE-FALL BALLISTIC CHART
}

G. W. Stone

THIS DOCUMENT CONFIRMED AS UNCLASSIFIED DIVISION OF CLASSIFICATION BY OH Kahn lamh

Reentry and Space Sciences Division 


\section{DISCLAIMER}

This report was prepared as an account of work sponsored by an agency of the United States Government. Neither the United States Government nor any agency Thereof, nor any of their employees, makes any warranty, express or implied, or assumes any legal liability or responsibility for the accuracy, completeness, or usefulness of any information, apparatus, product, or process disclosed, or represents that its use would not infringe privately owned rights. Reference herein to any specific commercial product, process, or service by trade name, trademark, manufacturer, or otherwise does not necessarily constitute or imply its endorsement, recommendation, or favoring by the United States Government or any agency thereof. The views and opinions of authors expressed herein do not necessarily state or reflect those of the United States Government or any agency thereof. 


\section{DISCLAIMER}

Portions of this document may be illegible in electronic image products. Images are produced from the best available original document. 
Issued by Sandia Corporation,

a prime contractor to the United States Atomic

Energy Commission

\section{NOTICE}

This report was prepared as an account of work sponsored by the United States Government. Neither the United States nor the United States Atomic Energy Commission, nor any of their employees, nor any of their contractors, subcontractors, or their employees, makes any warranty, express or implied, or assumes any legal liability or responsibility for the accuracy, completeness or usefulness of any information, apparatus, product or process disclosed, or represents that its use would not infringe privately-owned rights.

Available from National Technical Information Service, Springfield, Va 22151

Prlce: Paper copy $\$ 3.00$ Microfiche $\quad .65$. 


\title{
SC $-R R-70-881$
}

\section{A THEORETICAL EXPLANATION OF A VERTICAL FLIGHT FREE-FALL BALLISTIC CHART}

\author{
G. W. Stone \\ Reentry and Space Sciences Division \\ Sandia Laboratories \\ Albuquerque, New Mexico \\ 87115
}

The cutoff date for information

in this report is December 1970

\section{ABSTRACT}

A theoretical analysis of the translational motion of objects dropped from rest at altitude is performed to explain the inherent characteristics of a ballistic chart that was developed by empirical means.

December 1970

LEG A L NOTICE

This report was prepared as an account of work sponsored by the United States Government. Neither the United States nor the United States Atomic Energy Commission, nor any of their employees, nor any of their contractors, subcontractors, or their employees, makes any warranty, express or implied, or assumes any legal liability or responsibility for the accuracy, completeness or usefulness of any information, apparatus, product or process disclosed, or represents that its use would not infringe privately owned rights.

Key Words: Trajectories, impact 
BLANK 


\section{Summary}

An empirical free-fall ballistic chart that is used very frequently at Sandia Laboratories gives the velocity of an object that was released from rest if the distance fallen and the time of fall are known. This chart, developed using experimental drop test data and some supplementary point mass trajectory calculations, gives accurate results that are independent of altitude and vehicle ballistic coefficient whenever the distance fallen is less than approximately 10,000 feet and the ballistic coefficient is constant. The chart is applicable to freely falling stable vehicles, parachute retarded vehicles, and tumbling bodies that rotate rapidly enough to satisfy the condition of a constant average drag coefficient.

This analysis develops the inherent theoretical basis for the ba1listic chart and shows why, through the unique presentation, the chart does not depend explicitly on either altitude or body characteristics. 


\section{List of Symbols}

A - Aerodynamic reference area, $\mathrm{ft}^{2}$.

$C_{D}$ - Drag coefficient.

$g$ - Acceleration of gravity, $\mathrm{ft} / \mathrm{sec}^{2}$.

m - Vehicle mass, slugs.

$\mathrm{S}$ - fall distance, ft.

$t$ - Time, seconds.

V - Velocity, ft/sec.

W - Vehicle weight, lbs.

$B$ - Vehicle ballistic coefficient, $W / C_{D} A$ lb/ft ${ }^{2}$.

$\gamma$ - Constant defined in Equation 7, $1 / \mathrm{sec}$.

$\lambda$ - Atmospheric scale height for exponential density, $1 / f t$.

$\rho$ - Atmospheric density, slugs $/ \mathrm{ft}^{3}$. 


\section{A THEORETICAL EXPLANATION OF A VERTICAL FLIGHT FREE-FALL BALLISTIC CHART}

\section{Introduction}

Several years ago, Mr. W. V. Hereford of Sandia Laboratories deve1oped a very useful ballistic chart (Figure 1) that gives the velocity of an object falling vertically from rest if the time of flight and the distance fallen are known. The chart was developed using a large amount of experimental and numerical trajectory data for all types of vehicles, with and without parachutes, dropped at altitude with little or no velocity. The chart has been used extensively by the Aerospace Nuclear Safety Department of Sandia Laboratories for the estimation of SNAP capsule terminal velocities, and it is known to give accurate results.

One interesting characteristic of the chart is that altitude (atmospheric density) and vehicle characteristics (weight, area, and drag coefficient) do not appear explicitly. The purpose of this analysis is to develop a simplified theory for the chart and to show why the results do not depend explicitly on the altitude and the vehicle parameters.

Theory

The translational motion of a body with constant mass falling vertically through the atmosphere of a nonrotating planet is governed by the differential equation

$$
\mathrm{m} \frac{\mathrm{dV}}{\mathrm{dt}}=\mathrm{W}-\frac{\mathrm{PAC}_{\mathrm{D}}}{2} \mathrm{v}^{2}
$$


or

$$
\frac{d V}{d t}=g-\frac{\rho A C}{2 m} V^{2}
$$

The ballistic coefficient of the vehicle is given by

$$
\beta \equiv \frac{W}{C_{D}^{A}}
$$

and Eq. (2) can be written as

$$
\frac{d V}{d t}=g\left[1-\frac{\rho V^{2}}{2 \beta}\right]
$$

Transferring from time to distance travelled as the independent variable in Eq. (4) gives

$$
\frac{d\left(V^{2}\right)}{d S}=2 g\left[1-\frac{\rho V^{2}}{2 \beta}\right]
$$

If the analysis is now restricted to changes in altitude of approximately 10,000 feet or less so that the atmospheric density can be assumed constant, $\rho=\rho_{0}$, and if the vehicle ballistic coefficient is constant, Eqs. (4) and (5) have the solutions, respectively,

$$
V^{2}=\frac{2 \beta}{\rho_{0}}\left[\frac{e^{\gamma t}-1}{e^{\gamma t}+1}\right]^{2}=\frac{2 \beta}{\rho_{0}} \tanh ^{2}\left(\frac{\gamma t}{2}\right),
$$

where

$$
Y=g \sqrt{\frac{2 \rho_{0}}{\beta}}
$$

and 


$$
\mathrm{V}^{2}=\frac{2 \beta}{\rho_{\mathrm{o}}}\left[1-\mathrm{e}^{-\frac{\rho_{\mathrm{o}} g}{\beta} \mathrm{S}}\right]
$$

for the initial conditions that $V=0$ when $S$ and $t$ are zero.

Equations (6) and (8) can be combined to give

$$
S=\frac{2 \beta}{\rho_{0} g}\left[\ln \left(\frac{e^{\gamma t}+1}{2}\right)-\frac{\gamma t}{2}\right] \text {, }
$$

or alternately

$$
t=\frac{1}{g} \sqrt{\frac{\beta}{2 \rho_{0}}} \ln \left[\frac{1+\sqrt{1-e^{-\frac{\rho_{o} g}{\beta} S}}}{1-\sqrt{1-e^{-\frac{\rho_{0} g}{\beta} S}}}\right] .
$$

The effects of atmospheric and vehicle characteristics on the motion of the body appear in Eqs. (6) through (10) only as the ratio $\rho_{o} / \beta$, and it is this behavior that eliminates the explicit appearance of altitude and ballistic coefficient in the ballistic chart shown in Figure 1. If either Eq. (6) or (8) could be solved explicitly for $\beta / \rho_{O}$, the resulting equation could be substituted into either Eq. (9) or (10) to give an equation relating distance and time, with velocity as a parameter, which would yield the curves of Figure 1 . Although this result cannot be obtained algebraically, it can be achieved without difficulty by either graphical or numerical methods.

Equations (6) and (8) were used to calculate the typical variations of velocity with distance fallen and time of fal1, shown in Figures 2 and 3 , respectively, using representative values of $\beta / \rho_{0}$ corresponding to altitudes from 5000 to 45,000 feet and ballistic coefficients ranging from 10 to $200 \mathrm{lb} / \mathrm{ft}^{2}$. Equation (9) was used to calculate the variation of distance fallen with time shown in Figure 4. Figures 2, 3, and 4 are typical of common ballistic charts having altitude and ballistic coefficients as parameters. 
In the pretest planning of free-fall drop tests, it is often necessary to know the minimum drop altitude that will allow the vehicle to reach terminal velocity. This information can be obtained by writing $\mathrm{Eq}$. (8) in the form

$$
\mathrm{S}=-\frac{\beta}{\rho_{\mathrm{o}} \mathrm{g}} \ln \left[1-\frac{\mathrm{V}^{2}}{\mathrm{~V}_{\mathrm{T}}^{2}}\right] \text {, }
$$

where

$$
\mathrm{V}_{\mathrm{T}}^{2}=\frac{2 \beta}{\rho_{\mathrm{o}}}
$$

Equation (11) was used to calculate the altitude necessary to allow the vehicle to reach 99 percent of $V_{T}$ shown in Figure 5.

The data shown in Figures 2 and 3 were used to construct the theoretical free-fall ballistic chart shown in Figure 6 . Several points from the empirical chart are plotted for comparison. It can be seen that the agreement is good. For large fall distances, the empirical data are slightly above the theoretical curves; this demonstrates the effect of the actual nonconstant density variation with altitude in the empirical method.

In general, efforts to include variable atmospheric density in the analysis encounter difficulties in the integration of the equations. For variable density, Eq. (5) generally can be integrated without difficulty to give the square of the velocity in terms of either atmospheric density or distance travelled, but the integration for distance in terms of time is generally very difficult, if not impossible, to obtain analytically. For example, with the exponential density variation

$$
\rho=\rho_{0} e^{\lambda S}
$$

Eq. (5) has the series solution 


$$
\begin{aligned}
\mathrm{V}^{2}= & \frac{2 g}{\lambda} e^{\frac{g \rho_{\mathrm{o}}}{\lambda \beta} \frac{\rho}{\rho_{\mathrm{o}}}}\left\{\ln \frac{\rho}{\rho_{\mathrm{o}}}-\frac{g \rho_{\mathrm{o}}}{\lambda \beta}\left(\frac{\rho}{\rho_{\mathrm{o}}}-1\right)+\left(\frac{g \rho_{\mathrm{o}}}{\lambda \beta}\right)^{2} \frac{1}{2.2 !}\left(\frac{\rho^{2}}{\rho_{\mathrm{o}}^{2}}-1\right)-\right. \\
& \left.\left(\frac{g \rho_{\mathrm{o}}}{\lambda \beta}\right)^{3} \frac{1}{3.3 !}\left(\frac{\rho^{3}}{\rho_{\mathrm{o}}^{3}}-1\right)+\ldots\right\}
\end{aligned}
$$

with the initial conditions $V=0$ when $S=t=0,\left(\rho=\rho_{0}\right)$. It can be seen from Eq. (14) that, for a given fall distance (i.e., density ratio), the velocity of a vertically falling vehicle depends only upon the ratio of the initial atmospheric density to the vehicle ballistic coefficient.* As a result, the chart presented in Figure 1 still would not depend on either altitude or vehicle parameters and the chart can be extended to larger fall distances by using experimental data or numerical integration of the equations of motion with the one restriction of a constant vehicle ballistic coefficient.

\section{Conclusions}

A theoretical analysis of the translational motion of vertically falling objects has been performed to explain the inherent characteristics of an empirical free-fall ballistic chart. It has been shown that, for a given planetary model, the motion of an object falling from rest with a constant ballistic coefficient depends on the single parameter $\rho_{0} / \beta$. Because of this behavior, the unique presentation of the ballistic chart does not contain an explicit dependence on release altitude or vehicle size, weight, or shape.

* This characteristic of vertically falling bodies is valid for any density variation that can be written as $\rho=\rho_{O} f(S)$ where $f(S)$ is a function of $S$ only that is applicable throughout the atmosphere. If $f(S)$ is applicable only to one zone of the atmosphere, the dependence of the trajectory on a single parameter would not hold for vehicles dropped in different altitude zones. 


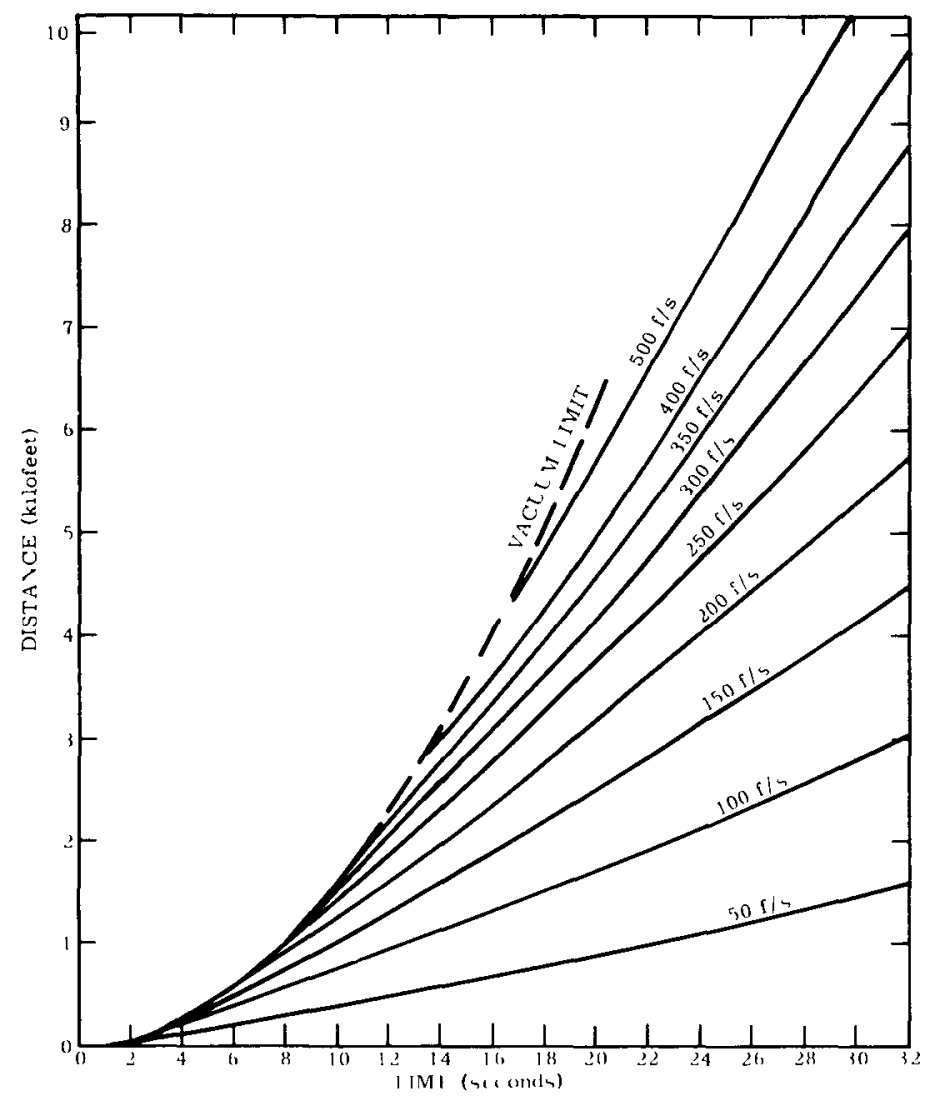

Figure 1. Empirical free-fall ballistic chart that gives the velocity of an object released from rest if the distance fallen and time of fall are known

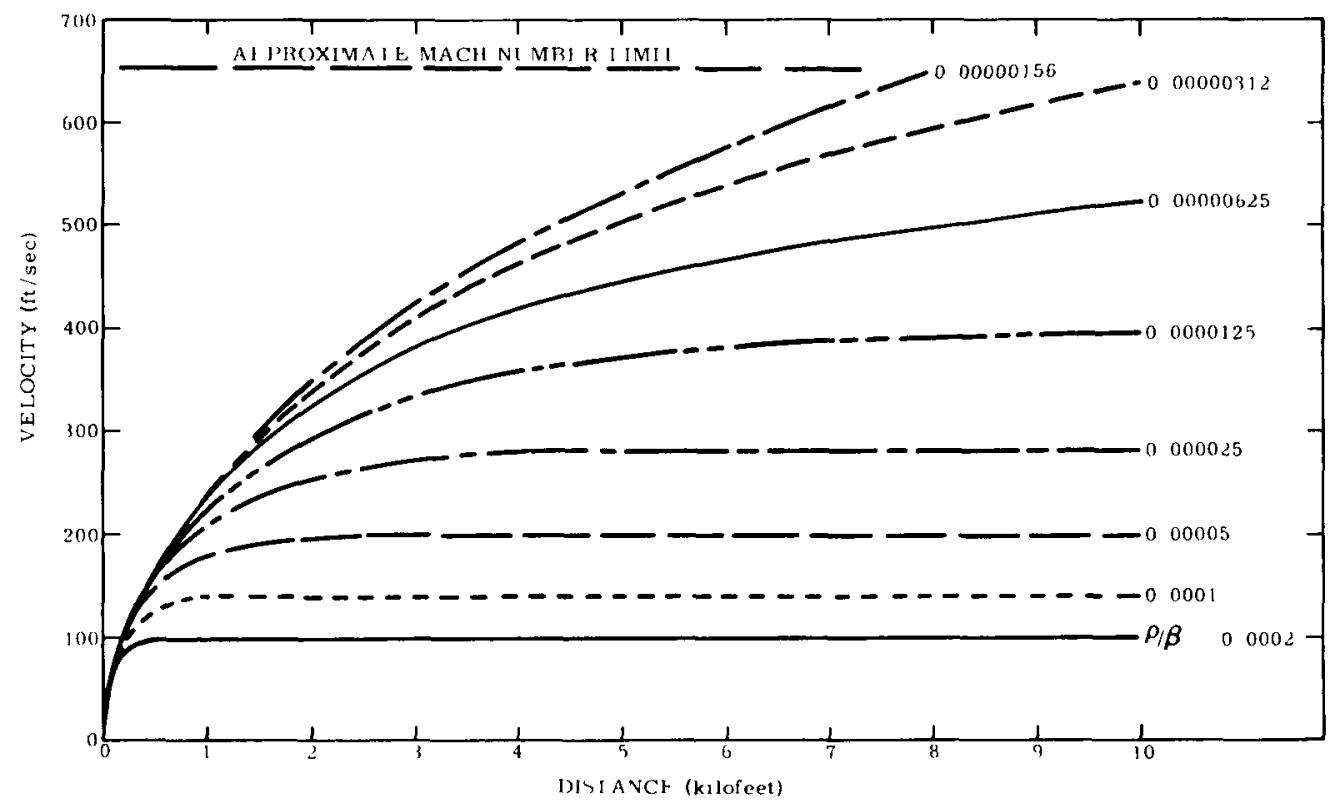

Figure 2. The theoretical variation of fall velocity with distance from release for constant atmospheric density 


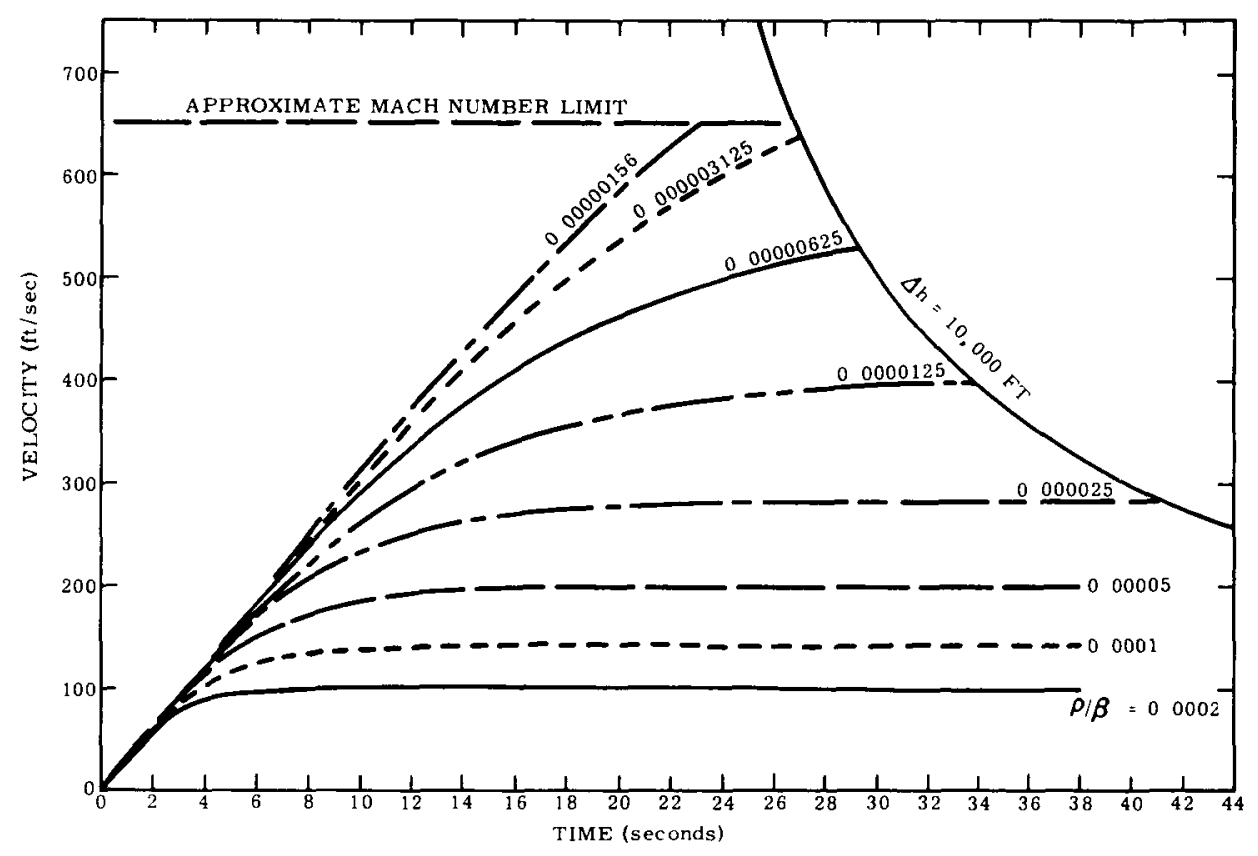

Figure 3. The theoretical variation of fall velocity with time from release for constant atmospheric density

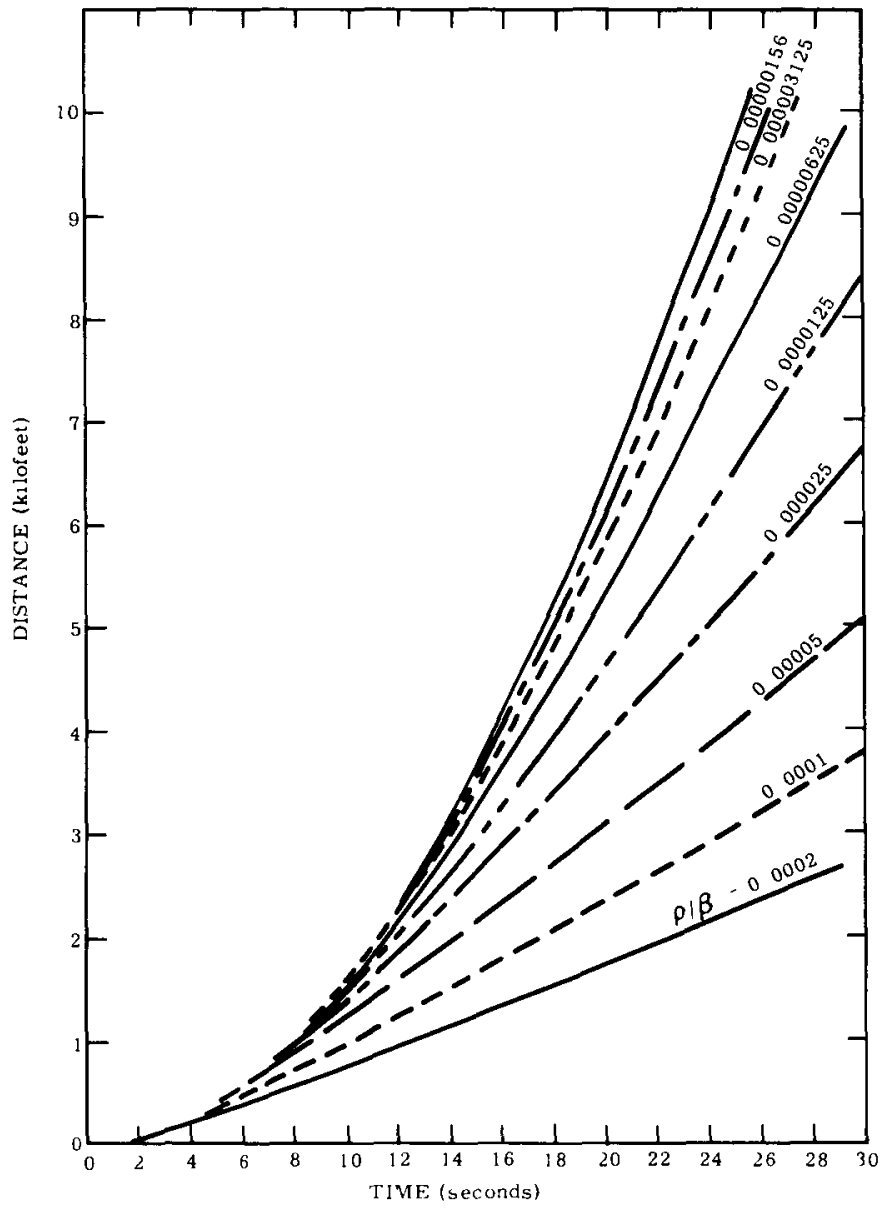

Figure 4.

The theoretical variation of distance travelled with time from release for constant atmospheric density 


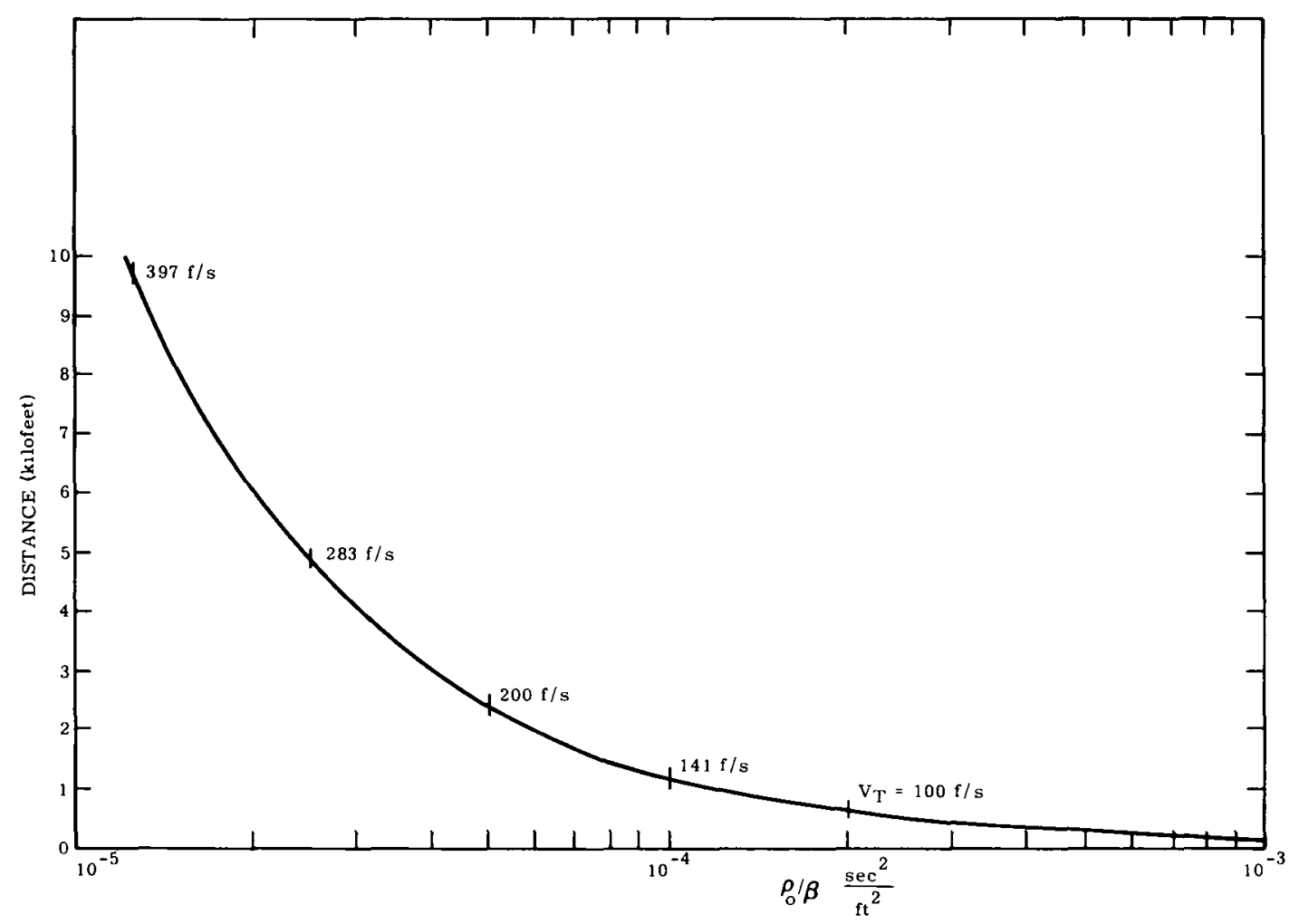

Figure 5. The variation of the fall distance necessary to reach $0.99 V_{T}$ with the density ratio $\rho_{\mathrm{O}} / \beta$ for constant atmospheric density

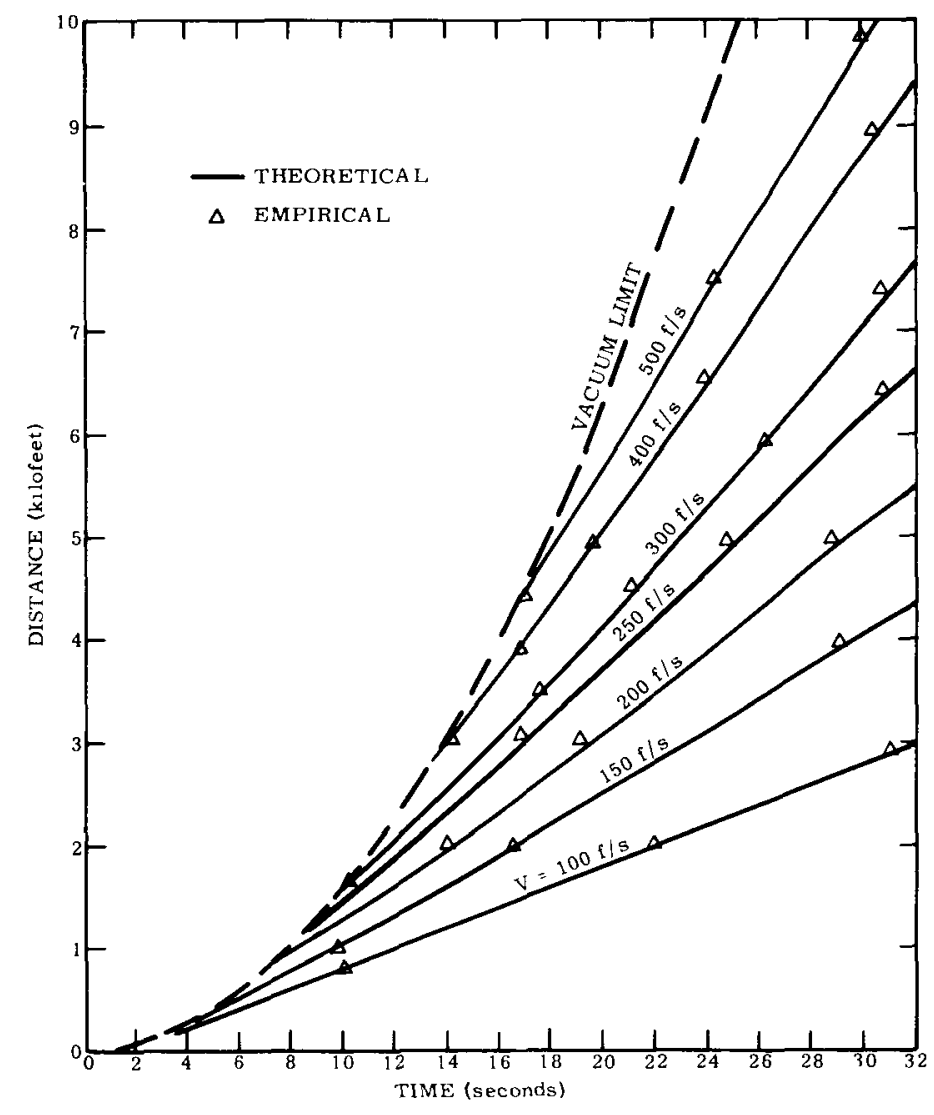

Figure 6.

Comparison between the theoretical and empirical results for the free-fall ballistic chart 
TID-4500 (56th Ed.) UC-36 (150)

U.S. Atomic Energy Commission (5) Division of Space Nuclear Systems Space Electric Power Office Wa shington, D.C. 20545

Attn: G. A. Newby Assistant Director G. P. Dix Chief, Safety Branch

H. Jaffe Chief, Isotope Power Systems Branch

J. A. Powers Chief, Isotopes Fuels and Materials Branch

C. E. Johnson Chief, Reactor Power Systems Branch

U.S. Atomic Energy Commission Space Nuclear Propulsion Office Washington, D.C. 20545

Attn: R. S. Decker, Jr., Chief, Safety Branch

U.S. Atomic Energy Commission Division of Isotope Development Washington, D.C. 20545

U.S. Atomic Energy Commission (2) Director of Regulation Washington, D.C. 20545 Attn: C. K. Beck Deputy Director R. W. Klecker Division of Reactor Licensing

U.S. Atomic Energy Commission (2) Division of Biology and Medicine Washington, D.C. 20545

Attn: J. Z. Holland Fallout Studies Branch H. D. Bruner Assistant Director Medical and Health Research

U.S. Atomic Energy Commission Space Nuclear Propulsion Office Albuquerque Extension Albuquerque Operations Office P.O. Box 5400

Albuquerque, New Mexico 87115

Attn: H. P. Smith
U.S. Atomic Energy Commission Albuquerque Operations Office P.0. Box 5400 Albuquerque, New Mexico 87115

Attn: V. V. Berniklau Director, Space and Special Projects Division For: J. Nicks

J. F. Burke Director, Operationa 1 Safety Division

AEC Site Representative National Aeronautics and Space Administration

Manned Spacecraft Center

Houston, Texas 77058

Attn: W. C. Remini Bldg. 16, Code ZS-5

Deputy I. G. for Inspection \& Safety USAF

Directorate of Nuclear Safety Nuclear Power Division

Kirtland Air Force Base New Mexico 87117

Jet Propulsion Laboratory

California Institute of Technology 4800 Oak Grove Drive

Pasadena, California 91103

Attn: A. L. Klascius Radiation Health and Safety

Los Alamos Scientific Laboratory

P.O. Box 1663

Los Alamos, New Mexico 87544

Attn: Dr. L. D. P. King

Dr. Wright Langham

C. F. Metz, CMB-1

F. W. Schonfeld, CMF-5

J. A. Leary, CMB-11

Monsanto Research Corporation Mound Laboratory

P.O. Box 32

Miamisburg, Ohio 45342

Attn: G. R. Grove

Thomas B. Kerr

Code RNS

National Aeronautics and Space

Administration

Washington, D.C. 20545 
DISTRIBUTION : (cont)

Mr. Glenn Goodwin

National Aeronautics and Space

Administration

Ames Research Center

$\mathrm{N}-200-4$

Moffett Field, California 94035

National Aeronautics and Space Administration

Goddard Space Flight Center

Glenn Dale Road

Greenbelt, Maryland 20771

Attn: A. W. Fihelly

Nimbus Project

Nava1 Facilities Engineering Com

Dept. of the Navy, Code 042

Washington, D.C. 20390

Space Nuclear Propulsion Office

Lewis Research Center

21000 Brookpark Road

Cleveland, Ohio 44135

Attn: L. Nichols

Mr. George Mande1

Information Specialist

Aerospace Safety Research and

Data Institute

NASA Lewis Research Center

21000 Brookpark Road

Cleveland, Ohio 44135

Union Carbide Corporation

Nuclear Division

P.O. Box X

Oak Ridge, Tennessee 37831

Attn: R. A. Robinson Isotope Development Center

B. R. Fish

Health Physics Division

U.S. Public Health Service

Nat. Ctr. for Radiological Health

1901 Chapman Avenue

Rockville, Maryland 20852

Attn: Nuclear Facilities Section
D. B. Shuster, 1200

J. R. Holland, 5321

W. V. Hereford, 7291

C. F. Bild, 7300

G. A. Fowler, 9000

J. R. Banister, 9150

R. C. Maydew, 9320

L. A. Hopkins, Jr., 9500

A. J. Clark, Jr., 9510

S. L. Jeffers, 9512

ARPIC, 9512 (2)

S. McAlees, Jr., 9513

G. W. Stone, 9513 (5)

Central Files, 3422-1

L. C. Baldwin, 3412

L. L. Alpaugh, 3412

G. C. McDonald, 3416

Attn: P. S. Wilson 